\title{
Indonesian Online Tourism Promotion: a Rhetorical and Discoursal Look
}

Diah Kristina, Ph. D.

Prof. Tulus Haryono

M. Ek. , Rara Sugiarti, M. Tourism. Sebofelas Maret University

Solo, Indonesia.

Abstract

\begin{abstract}
The new media offer a much wider opportunity for international recognition including the promotion of tourism destination in Indonesia. This study aims at exploring the ways tourist destinations in Central Java, Indonesia are promoted on the website done by five different online promotion developers. There were 20 online promotional texts scrutinized to see their typical characteristics using theories of Critical Discourse Analysis proposed by Dijk (1998) and Kress (2010). The research findings reveal that generally the online promotional texts were constructed as descriptive genres most of which were composed in simple and compound sentences. There were relatively limited numbers of complex sentences employed. The mental model of the texts typically shows a great concern to the history, philosophy, cultural myth and geographical location of the tourist destinations under discussion. Typical use of imperatives commonly found in advertisements seems to be hardly available. Likewise, rhetorical questions that function to engage readers are unlikely existing in the online promotion of tourist destination of Central Java developed by the Indonesian government and other private agents. In contrast, the online promotion of tourist destination of more developed institutions like the Singaporean and Malaysian government makes use of recount genre that functions as a testimony. For a thicker description of findings, in-depth interviews with English speaking tourists were also conducted.
\end{abstract}

Keywords: tourist destination, rhetorical question, testimony.

\section{Introduction}

With the coming of the new media, business florishes dramatically including the hospitality industry in Indonesia. The www. emarketer. com reported in 2014 that internet users all over the globe will hit the peak of 3 billion in 2015 and nearly half of the world's population will have regular access to the web by 2018. Additionally, the Indonesian internet users will reach the top five overtaking Japan by 2017 showing how significant this new media for business, official and private communication purposes. Hasbrouck (2001) argues that the development of information is parallel with the development of people's movement, power and money. Historically, the global electronic web was believed to be initially drawn from the rapid expansion of the travel industry.

With respect to tourism industry, the Indonesian government set up a target of 7 millions tourists visiting this country in 2014. For that reason, promotion of tourist destination to foreigners using the language that attracts and motivates them is considered crucial. The language that persuades, reaches out and engages the prospective visitors is assumed to have an important role, not only to attract but also to motivate, to convince and to booze the tourists'curiousity.

This article aims at exploring the Indonesian online tourism promotion made by 5 online promotion developers namely, Ministry of Tourism of the Republic of Indonesia, Tripadvisor, www. eastjava. com, Budha Dharma Education Association 1996-2012, and Lonely Planet. 8 validated online texts among 20 available online texts were selected for the primary data and tentatively 4 English speaking informants were requested to look at and read the online tourism promotion texts. Since the study is still in progress, other four informants of much younger age group will be interviewed and an additional focus group discussion with the stakeholders will be also conducted. Theoritical insights were drawn form theories proposed by Dijk (1998) and Kress (2010) and used as analytical lenses.

\section{Related works and their relevance to the current work}

Some works are considered relevant to this work among others are Novalina (2008) who studied the role of tourist promotion in the Ministry of Tourism and Culture Bandung District to motivate tourists to visit Bandung and the sorroundings. However, 
this study did not address the significant role of language in promoting the destination. Another closely related study may be the work of Muhammad Arifin Bin Salim, et. al (2012). This study was done as a review of literature using online database by employing 3 keywords namely, tourism, tourism discourse and language of tourism. The previous work certainly differs from the current work in terms of nature of the research and data collecting techniques inwhich the present study is etnographical. In terms of effectiveness of the online promotion, the work of Kim and Fesenmaier ( (2008) might be relevant to this work in the aspect of persuasiveness of the destination websites but not the language to express the message inwhich the researchers investigated users first impression and quick judgment on the online texts.

Seaton \& Bennet (1996:179) state that promotion and tourism has particular objectives. They argue that 'Effective promotion starts, like any other marketing activity, from an analysis and clear formulation of strategic objectives. These involve: (1) identification of the target audiences to be reached; (2) identification of the communication goals to be achieved with each; (3) formulation of messages designed to achieve the goals; (4) choice of media for delivering the messages effectively to the designated audiences; (5) allocation of a budget to achieve the production and delivery of the messages; and (6) evaluation mechanism in terms of sales, direct action or communication measurers'.

Considering the objectives of tourism promotion proposed by Seaton \& Bennet (1996), the current work especially focuses on the third objective namely, formulation of messages designed to achieve the goals. In this respect the study is done by looking at the way the language of online tourist promotion is formulated in order to persuade, motivate and change behavior of the prospective tourists.

\section{Research Method}

Under the research method, some sub-topics are set namely, research design, data and data resources, data collecting technique, data analysis, validity and reliability of data.

\section{1. Research design}

The present study belongs to descriptive - qualitative and etnographical type of research. Descriptive refers to an objective representation of phenomena investigated by the researcher. The phenomena being investigated are the English expressions and their persuasive elements used in the online tourism promotion in Central Java, Indonesia, the verbal convention and effectiveness of language use in the online texts. The etnographical qualities of the study were drawn from the observation and in depth interviews with the informants as users of the online tourist promotion.

\section{2. Texts used}

The texts used were online tourist promotion texts on the websites made by 5 tourism promotion web-developers namely Ministry of Tourism of the Republic of Indonesia, Tripadvisor, www. eastjava. com, Budha Dharma Education Association 1996-2012, and Lonely Planet. Actually, there are 22 Indonesian online promotion texts on the web that promote Central Java. However, after validated, 12 texts from the Indonesian web developers were selected and other 4 online texts developed by the Malaysian and Singaporean web developers were used as cross-checkers.

\section{3. Data and data resources}

The primary data were words, phrases, clauses and sentences drawn from the online tourist promotion of Central Java destination. Besides, the secondary data were information taken from observation and indepth interviews with 4 foreign visitors from USA, Australia and Chille. The informants were professionals and selected based on their age group as different age-group is assumed to have different expectations on how the online tourist promotion should sound and look in order to persuade them to visit the destination. 


\section{4. Techniques of collecting data}

Taking into account the nature of the study as a descriptive- qualitative and ethnographical study, the technique of collecting data is presented as follows:

a. $\quad$ Data were collected from online tourist promotion texts developed by 5 Indonesian website developers.

b. In depth interviews in a semi-structured way were carried out to get reliable and comprehensive information from the informants.

c. Informal observation and talks were done with members of the freelance tourism community who upload new destinations on the Instagram.

\section{5. Data and data analysis}

The source data of this study were Indonesian online tourist promotional texts focusing on Central Java destinations. Additionally, the primary data of the study were words, phrases, clauses and sentences in the online texts while the secondary data were information collected during the in depth interviews witth the informants. The data analysis was done using the macro, micro and super structure analysis proposed by van Dijk (1998) and multimodal perspectives advocated by Kress (2010).

\section{6. Validity and realibility}

Validity of the source of data for the study is obtained based on the face validity in which the online texts were taken from the Google search engine with the keyword of 'online tourism destination in Central Java'. To add, the reliability is achieved by making sure that 'the findings obtained are consistant with the data collected' (Merriam, 1998:206).

\section{Results of the study}

The general assumption drawn by viewers from the online tourist promotion developed by the Indonesian Ministry of Tourism (http://www. indonesiatravel/en/discover-indonesia/region-detail/32/cen) is the opinion that central Java is rich in culture (Sentence $1 \& 3$ ), has an extensive network of good roads and railways that link major cities and villages (S 9,10 , 11), uses culinary specific to every city as one of the main attractions $(S 16,17,18,19)$. In terms of rhetorical structure, the producer of the online text employs a strategy of describing the historical background of Central Java since the Hindhu, Buddhist and Islamic reigns (S 1-5), the Dutch occupation (S 6, 7) and the Indonesian independence (S 8-27). Textually, the online promotion is constructed from 20 simple sentences, 8 compound sentences and 1 complex sentence. Syntactically, those sentences are developed using pre and post modifiers in the form of noun and adjunct phrases. At first impression, the online promotion text looks short and simple but lacking of substantial information seeked by the foreign tourist like suggested by informant 2 below.

'I didn't find this is very useful as a matter of fact I try to do a lot of online research before I am coming here. . . there is a small number of information and the information is very basic and the photos. . . it's hard to get the sense of how beautiful it is. ' (interview conducted on Sunday, June 21, 2015).

Contrary to the $2 \mathrm{nd}$ informant, the $1 \mathrm{st}$ and the $3 \mathrm{rd}$ informants found the information in the online promotion help them to have an initial knowledge of the destination and the photo of Borobudur temple creates a 'mystical feel because it helps viewers to enjoy the atmosphere of some sanitized place that facilitates an escape from routine' (interview conducted on Friday, June 19, 2015). The 4 th informant even highlights how inportant pictures or photographs have been for prospective tourists to come and visit the destination: 'of course photos are the first thing I am looking for before coming here' (interview conducted on Sunday, June 21, 2015).

The imperative construction typical to advertisements and modalities showing obligation are used in a very limited way for example 'be sure to visit. . .' (7); 'try the lumpia. . ' ' (8); ' if you like religious objects, you should visit. . .' (10); 'you could trace. . . ' (10). Likewise, the discoursal strategy employed has been creating a mental model of mixing history, culture, tradition and panoramic views as the main point of tourism attractions and that the text is presented descriptively and 
informatively with minimal engagement between the text producer and the online promotion viewers shown by the absence of rhetorical questions and limited gimmick expressions to reach out the audience.

The second online text developed by the Budha Dharma (http://www. buddhanet. net/borobudur) uses the historical perspective to pass on information about Borobudur temple (S1-3 and S10-13) embedded by physical structure of the temple in between. Since the online promotion text offers a particular object to visit, therefore a descrption of its historical background and phyisical appearance is presumably considered significant by the text producer. Likewise, the online text is constructed descriptively with relatively equal use of simple and compound sentences. The engangement between the text producer and the text consumer seems distant as the former provides information and the latter consume the information. It therefore lacks of persuasive values.

The third online text was developed by lonely planet. com and is available at www. lonelyplanet. com/indonesia/centraljava. The mental model induced by the text producer makes use of factual appearance of Jakarta city as a modern place with traces of Javanese historical tradition. The ideology behind the text construction is presenting Jakarta as a mix between Java's past and future. In its linguistic realization, the text producer employs bombastic words to attract readers/viewers like 'fair share of charm', 'bombastic tourist centres', 'intriguing fusion of Java's past and future', 'the stupendous Borobudur and Prambanan temples', 'this stunning island'. Syntactically, the text is composed of 3 simple sentences and 2 compound sentences and 1 complex sentence. Eventhough the online text is descriptive but the way the text producer constructs the sentences is made more variative.

The following online tourist promotion text to be scrutinized is the one developed by www. eastjava. com that describes about Dieng plateau. Similar to that of the second text, this online text is dominated by nominal sentences in which it has 22 simple sentences, 2 compound sentences and 3 complex sentences. In terms of discoursal strategy, the text describes the geographical location of the tourist site in terms of latitude and panoramic views.

With regard to the physical appearance, the online tourist promotion text developed by tripadvisor. com which is available at the http://www. tripadvisor. com seems to be completely different from the rest of the online promotion text explored in the study. There are two significant things that the developer inovates namely the use of reviews from visitors which are rated based on the categories of excellent, very poor, average, poor and terrible. Additionally, the reviews are functioned to provide testimonies to the prospective tourists. Even, they provide question and answer corners to address queries from visitors to the web master. Though some descriptions of the destination are almost always existing in the testimony however, the employment of modalities showing obligation is dominant. Some others use if clauses to create a more persuasive impression and direct invitation.

\section{Discussion}

The study has shown that the Indonesian online tourist promotion texts though provide important historical information of the tourism destination which are seeked for by potential tourists, they ought to have more comprehensive and up-dated information. In order to maximize their persuasive values they need rhetorical strategies which not only inform and describe but also invite, motivate and persuade these prospective tourists to make decissions for a visit. Beeton et. al (2005) argue that verbal messages needs to be deliberatedly manipulated to affect the hearts and minds of the audience. This argument therefore lies a strong ground for more energized verbal messages which can affect the hearts and minds of the potential tourists to make a favorable decission to visit the destination. In that case, a more substantial modification is needed to create a more persuasive online tourist promotion to the Indonesian tourist destination especially the Central Java online tourist promotion.

Furthermore, sophistication on the construction of the verbal messages needs to be improved in order to have a more natural and persuasive messages by reducing the dominant use of simple sentences. In terms of content however, the informants suggest to update the information on the online tourist promotion and provide list of events. Besides, an addition of testimony and review of the toursist destination might help potential tourists to make up their mind.

Likewise, the Indonesian online tourist promotion developers might be able to learn from Singapore and Malaysia in making their descriptive texts of online promotion sound more motivating using more variative construction of English sentences. The employment of gimmick language and rhetorical questions to attract and persuade audience needs to be considered. 
In the visual presentation of the online tourist promotion, what the Indonesian developers can adopt is the use of three colummns picture and rubric which are more practical and efficient to get the information with.

\section{Vl. Conclusion and implications}

After looking very closely at the Indonesian online tourist promotion produced by 5 websites developers, a conclusion can be drawn as follows:

1. The Indonesian online tourist promotion texts generally are drawn from a mix of history, culture, tradition and panoramic views as their point of attractions.

2. The texts were typically descriptive and informative in nature. Consequently, they were less persuasive.

3. Syntactically, most of the Indonesian online tourist promotion texts were constructed in simple sentences and compound sentences. Only a small number of complex sentences are used.

4. A substantial modification needs to be made in terms of comprehensiveness, up-dated information, writing style, discoursal strategies, visual presentation.

5. The employment of rhetorical questions for persuasive purposes, reviews of destination, testimonial discourses and questions \& answers forum needs to be seriously considered.

The above conslusions bear some implications on the modelling of persuasive online tourist promotion texts acceptable to users. Additionally, the websites developers need to equip themselves with the knowledge of persuasive language to improve the quality of their jobs. Finally, various studies related to online tourist promotion should be encouraged.

\section{References}

[1] Beeton, S. Betty. W. , Sam. H. (2005). Contextual analysis for applying persuasive communication theory to managing visitor behavior: A scoping study at port campbel national park. Victoria: Crc for sustainable tourism Pty. Ltd.

[2] Bhatia. V. K. (1999). Integrating products, processes, purposes and participants in professional writing, in C. N. Candlin and K. Hayland (eds), Writing: Texts, Processes and Practices. London: Longman, 21-39.

[3] Bhatia, V. , K. (2004). World of written discourse: a genre based view: Advances in applied linguistics. London: Sage Publication.

[4] Dann, Graham. (1996). The language of tourism: A Sosiolinguistic perspective. Wallingford: CAB International.

[5] Dijk, Teun, A. van. (1997). Discourse as social interaction. Discourse studies: A multidisciplinary introduction Volume 2 (Ed). London: Sage Publication Ltd. Eriyanto. (2001). Analisis wacana: Pengantar analisis teks media. Jakarta: PT. Pelangi Aksara.

[6] Hasbrouck, E. (2001). The practical nomad: Guide to the online travel marketplace. Emeryville, USA: Avalon Travel Publishing.

[7] Kathpalia, Sudjata, S. (1992). A genre analysis of promotional texts. PhD thesis submitted to the National University of Singapore.

[8] Kristina, Diah, dkk. (2005). Efektifitas bahasa Inggris dalam brosur pariwisata di Solo Raya. Laporan Penelitian Dosen Muda. Puspari UNS.

[9] Kristina, Diah. (2011). A genre analysis of sales promotion letters and company profiles in an Indonesian batik industry. Unpublished Dissertation. Universiti Utara Malaysia.

[10] Kristina, Diah. (2011). Image building in English. Buku teks mengajar. Surakarta: Diploma 3 Bahasa Inggris. Fakultas Sastra dan Seni Rupa. Universitas Sebelas Maret.

[11] Kristina, Diah. (2014). Building trust and credibility: The rhetoric of positive self image in the advertorials of Garuda Indonesia. Proceeding dalam Kongres Internasional Masyarakat Linguistik Indonesia. Bandar Lampung, 19-22 Pebruari 2014.

[12] Limaye, M. R. (1984). The syntax of persuasion: Two business letters of request. Journal of Business Communication, 20/2, 17-30. 
[13] Swales, J. M. (2000). 'Language for specific purposes'. Annual Review of Applied Linguistics, 20, 59-76.

[14] Swales, J. M. (1990). Genre analysis: English in academic and research settings. Cambridge: Cambridge University Press.

[15] Kress, G. and Leeuwen, T. v. (2001). Multimodal discourse: The modes and media of contemporary communication. New York: Oxford University Press Inc.

[16] Kress, G. (2010). Multimodality: A social semiotic approach to contemporary communication. New York: Routledge.

[17] Lathifah, N. D. (2007). Analisis faktor-faktor yang mempengaruhi strategi adaptasi promosi ekspor bagi pengingkatan kinerja pemasaran ekspor: Studi kasus industri ekspor furniture di Jawa Tengah. Semarang: Universitas Diponegoro (Thesis). http://eprints. undip. ac. id/16992/1/DIAN_NURUL_LATHIFAH. pdf

[18] Miles, M. B. \& Hberman, A. M. 1984. Qualitative data analysis: A sourcebook of new methods. London: Sage Publication.

\section{Journal articles}

Heejun, K. And Fesenmaier, D. R. , (2008). Persuasive design of destination websites: An analysis of first impression. Journal of Travel Research, Vol. 47. August 2008: 3-13. DOl: 10. 117/0047287507312405: Sage Publication.

Muhammad Arifin Bin Salim, Noor Aireen Binti Ibrahim, Hanita Hassim. (2012). Language for tourism: A review of literature. Elsevier Ltd.

\section{Appendixes}
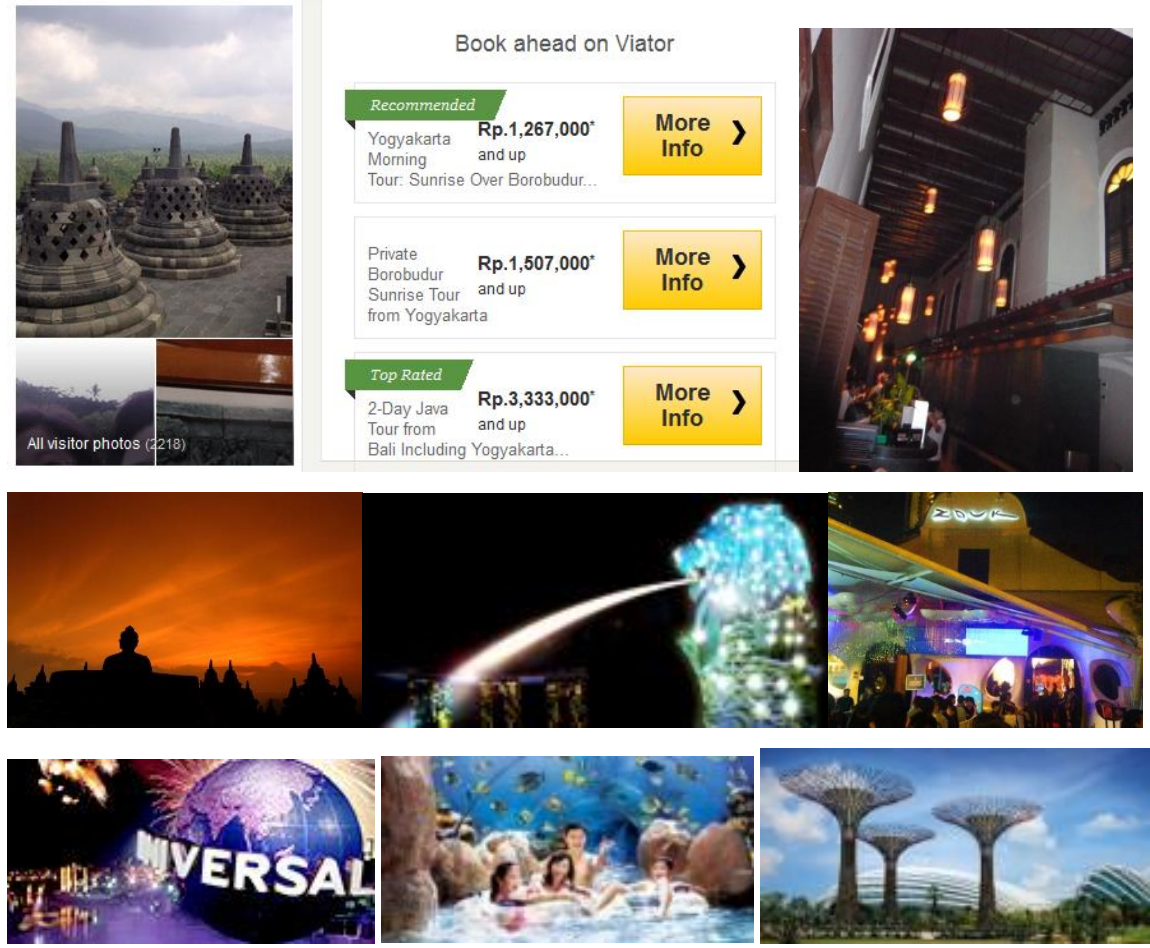